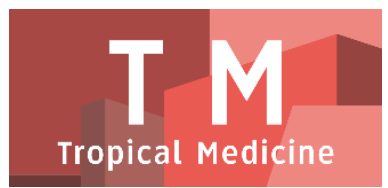

PAPER - OPEN ACCESS

\title{
Gambaran Empati Perawat Dalam Memberikan Asuhan Keperawatan Di Ruang Rawat Inap Rsup H. Adam Malik Medan
}

\author{
Author : Ranafika Butarbutar \\ DOI $\quad: 10.32734 /$ tm.v1i1.29 \\ Paper Page : $1-5$
}

Volume 1 Issue 1 - 2018 TALENTA Conference Series: Tropical Medicine (TM)

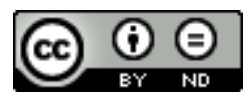

This work is licensed under a Creative Commons Attribution-NoDerivatives 4.0 International License.

Published under licence by TALENTA Publisher, Universitas Sumatera Utara
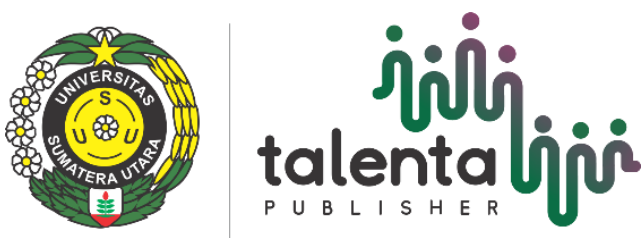


\title{
Gambaran Empati Perawat Dalam Memberikan Asuhan Keperawatan Di Ruang Rawat Inap Rsup H. Adam Malik Medan
}

\author{
Ranafika Butarbutar ${ }^{\mathrm{a}}$, Achmad Fathi ${ }^{\mathrm{a}, *}$ \\ ${ }^{a}$ Fakultas Keperawatan, Universitas Sumatera Utara, Medan 20155, Indonesia \\ ranafikabutarbutar@ymail.com
}

\begin{abstract}
Abstrak
Empati merupakan suatu proses memahami perasaan orang lain dan ikut merasakan yang orang lain rasakan. Empati dibagi menjadi dua komponen utama, yaitu kognitif dan afektif. Empati secara kognitif adalah proses memikirkan suatu situasi dari sudut pandang orang lain, sedangkan secara afektif akan membuat seseorang melakukan sesuatu untuk menolong dan menunjukkan kepeduliannya pada orang lain. Oleh karena itu empati menjadi sangat penting bagi seorang perawat untuk menjalin hubungan terapeutik dan juga berkomunikasi dengan pasien. Perawat yang memiliki empati, akan lebih mudah untuk menjalin hubungan terapeutik sehingga pasien akan lebih mudah menerima tindakan asuhan keperawatan. Penelitian ini bertujuan untuk mengidentifikasi gambaran empati perawat dalam memberikan asuhan keperawatan di ruang rawat inap RSUP H. Adam Malik Medan. Penelitian merupakan penelitian deskriptif dengan sampel 141 perawat pelaksana yang dipilih secara accidental sampling. Pengumpulan data dilakukan dengan menggunakan kuisioner dengan nilai koefisien reliabel 0,86. Analisis data dengan menggunakan analisis univariat. Hasil penelitian ini menunjukkan bahwa sebanyak 120 perawat $(85,1 \%)$ memiliki empati dalam kategori baik dan 21 perawat $(14,9 \%)$ dalam kategori cukup baik. Rekomendasi dari penelitian ini diharapkan agar pihak manajemen keperawatan rumah sakit terus meningkatkan kualitas pelayanan keperawatan pada pasien dan dalam waktu berkala melakukan evaluasi tentang kepuasan pasien terhadap pelayanan keperawatan.
\end{abstract}

Kata Kunci: Empati; Perawat

\section{Pendahuluan}

Empati merupakan kemampuan seseorang dalam memahami orang lain dengan seolah-olah masuk dalam diri orang lain sehingga bisa merasakan dan mengalami sebagaimana yang dirasakan dan dialami oleh orang lain itu, namun tanpa kehilangan identitas dirinya sendiri [8]. Empati pada dasarnya terdiri dari dua komponen utama, yaitu kognitif dan afektif [5]. Secara kognitif, seseorang cenderung memahami perasaan orang lain dengan membayangkan dan juga memikirkan suatu situasi dari sudut pandang orang lain, sedangkan secara afektif, lebih cenderung pada kemampuan seseorang untuk menyesuaikan perasaan orang lain dengan perasaannya sendiri yang pada akhirnya menghubungkan empati dengan perilaku menolong sebagai bentuk rasa kepedulian pada perasaan orang lain. 
Empati yang dimiliki seorang perawat merupakan kemampuan dan upaya perawat untuk memasuki kehidupan seorang pasien, untuk melihat dan merasakan perasaan pasien serta memahami makna perasaan tersebut bagi kehidupan pasien sehingga terjalin hubungan yang terapeutik antara perawat denga pasein [4]. Oleh karena itu memiliki sifat empati sangat dibutuhkan seorang perawat, selain untuk menjalin hubungan yang baik dengan pasien, empati juga diperlukan untuk mempermudah menggali permasalahan pasien, yang nantinya berguna untuk dapat mempercepat proses penyembuhan pasien [1].

Empati seorang perawat dalam memberikan asuhan keperawatan akan mempengaruhi kualitas pelayanan keperawatan. Perawat yang memiliki rasa empati yang baik dalam dirinya akan mampu meningkatkan kemampuannya dalam mengerti emosional yang sedang dialami pasien serta memberikan respon yang tepat terhadap emosional tersebut [5]. Namun saat ini banyak terdengar keluhan-keluhan pasien dan keluarga tentang buruknya pelayanan keperawatan di rumah sakit [1]. Keluhan yang sering terdengar mengenai sikap dan tindakan perawat yang mengecewakan dan tidak berempati misalnya, perawat sering marah-marah, tidak sabar, kurang perhatian, kurang tanggap, tidak mengerti kebutuhan pasien, kurang terampil, tidak memberikan rasa nyaman pada pasien, dan sebagainya [7]. Dari uraian di atas peneliti tertarik untuk melakukan penelitian tentang gambaran empati perawat dalam memberikan asuhan keperawatan di ruang rawat inap RSUP H. Adam Malik Medan.

\section{Metode}

Penelitian ini menggunakan desain penelitian deskriptif yang bertujuan untuk mengidentifikasi gambaran empati perawat dalam memberikan asuhan keperawatan di ruang rawat inap RSUP H. Adam Malik Medan. Populasi penelitian ini adalah seluruh perawat pelaksana yang bekerja di ruang rawat inap Rindu A dan Rindu B RSUP H. Adam Malik Medan yang berjumlah 217 orang perawat. Pengambilan sampel dilakukan dengan menggunakan accidental sampling dengan proporsi sampel yang diambil adalah $64,97 \%$ dari tiap ruangan yang ada di populasi, sehingga sampel yang didapat sebanyak 141 perawat. Pengolahan data statistik deskriptif untuk data demografi dan gambaran empati perawat disajikan dalam bentuk tabel data frekuensi dan persentasi

\section{Tabel, Gambar dan Peta}

\subsection{Hasil}

Karakteristik Demografi

Table. 1. Karakteristik Perawat

\begin{tabular}{lll}
\hline Karakteristik & Frekuensi (a) & Persentase (\%) \\
\hline Usia & 28 & 19.9 \\
$23-30$ Tahun & 41 & 29.1 \\
$31-38$ Tahun & 38 & 27.0 \\
$39-46$ Tahun & 34 & 24.1 \\
$47-54$ Tahun & & \\
(SD=8.226) & & \\
Jenis Kelamin & 134 & 95.0 \\
Perempuan & 7 & 5.0 \\
Laki Laki & & \\
\hline
\end{tabular}


Table. 2 Karakteristik Perawat (Lanjutan)

\begin{tabular}{lll}
\hline Karakteristik & Frekuensi (a) & Persentase (\%) \\
\hline Agama & 45 & 31.9 \\
Islam & 79 & 56.0 \\
Protestan & 17 & 12.1 \\
Khatolik & & \\
Suku & 68 & 48.2 \\
Toba & 33 & 23.4 \\
Karo & 7 & 5.0 \\
Mandailing & 13 & 9.2 \\
Jawa & 1 & 0.7 \\
Aceh & 3 & 2.1 \\
Minang & 6 & 4.3 \\
Melayu & 10 & 7.1 \\
Lainnya & & \\
Pendidikan Terakhir & 109 & 48.2 \\
D3 & 82 & 41.1 \\
S1 & 58 & 0.7 \\
S2 & 1 & \\
Lama Bekerja & & 10.9 \\
<1 Tahun & 48.3 \\
1 - 5 Tahun & & \\
\hline Total & & \\
\hline & & \\
\hline
\end{tabular}

Tingkat Empati Perawat

Table. 3 Gambaran Empati Perawat dalam Memberikan Asuhan Keperawatan

\begin{tabular}{lll}
\hline Empati Perawat & Frekuensi & Persentase (\%) \\
\hline Cukup Baik & 21 & 14.9 \\
Baik & 120 & 85.1 \\
\hline Total & $\mathbf{1 4 1}$ & $\mathbf{1 0 0}$ \\
\hline
\end{tabular}

Empati memiliki dua komponen utama, yaitu komponen kognitif dan juga afektif. Secara terpisah, komponen kognitif dan afektif ini memiliki hasil yang cukup berbeda.

Table. 4. Gambaran Empati Perawat Secara Kognitif

\begin{tabular}{lll}
\hline Kognitif Empati Perawat & Frekuensi & Persentase (\%) \\
\hline Cukup Baik & 43 & 30.5 \\
Baik & 98 & 69.5 \\
\hline Total & $\mathbf{1 4 1}$ & $\mathbf{1 0 0}$ \\
\hline
\end{tabular}


Table. 5. Gambaran Empati Perawat Secara Afektif

\begin{tabular}{lll}
\hline Afektif Empati Perawat & Frekuensi & Persentase (\%) \\
\hline Cukup Baik & 17 & 12.1 \\
Baik & 124 & 87.9 \\
\hline Total & $\mathbf{1 4 1}$ & $\mathbf{1 0 0}$ \\
\hline
\end{tabular}

\subsection{Pembahasan}

Hasil penelitian ini didapatkan bahwa empati perawat dalam memberikan asuhan keperawatan di ruang rawat inap Rindu A dan Rindu B RSUP H. Adam Malik Medan mayoritas pada kategori baik. Empati perawat yang baik akan membantu perawat dalam berkomunikasi dan menjalin hubungan interpersonal dengan pasien. Dari hasil penelitian ini, menunjukkan bahwa mayoritas perawat mengatakan betapa pentingnya mendengarkan keluhankeluhan pasien, merawat pasien dengan tulus, merasa senang ketika dapat membantu pasien dan keluarga, dengan sabar mendengarkan keluhan pasien, serta menghormati pasien dan keluarganya dengan tidak menyinggung mereka dengan apa yang dikatakan perawat.

Tinggi rendahnya empati yang dimiliki seseorang, khususnya pada penelitian ini adalah seorang perawat dalam memberikan asuhan keperawatan, diperngaruhi oleh banyak faktor-faktor, baik dari dalam diri perawat itu sendiri ataupun dari lingkungannya. Rasa empati yang dimiliki seseorang sebagian besar merupakan faktor bawaan dari dalam diri sendiri untuk bisa lebih peka terhadap orang lain. Namun, empati juga dapat ditingkatkan dan dikembangkan dalam kehidupan seseorang dengan melatih dan meningkatkannya seiring bertambahnya usia dan kematangan serta pemahaman tentang diri sendiri dan orang lain.

Tingkat empati perawat dalam kategori yang baik pada penelitian ini dapat dihubungkan dengan karakteristik perawat yang ada. Karakteristik perawat dalam penelitian ini memiliki rata-rata usia dewasa (39 tahun), mayoritas perawat adalah perempuan, dan lama berkerja kebanyakan adalah lebih dari 5 tahun. Koestner, Franz, dan Weinberger [3] mengatakan kemampuan empati seseorang akan semakin bertambah dengan meningkatnya usia, hal ini dikarenakan bertambahnya pemahaman perspektif. Usia perawat yang rata-rata adalah usia dewasa yaitu 39 tahun sudah memiliki pemahaman perspektif yang cukup. Perawat yang mayoritas berjenis kelamin perempuan juga memiliki perasaan yang lebih peka terhadap emosi orang lain dan lebih mudah mengekspresikan empatinya secara verbal dibandingkan laki-laki [4]. Baiknya tingkat empati perawat di rumah sakit ini juga dapat dihubungkan dengan perawat yang lebih banyak sudah bekerja lebih dari 5 tahun. Goleman pada [2] menambahkan kemampuan seseorang untuk mengenal dan berinteraksi dengan lingkungannya akan memungkinkan seseorang merasakan emosi yang berbeda-beda dari sekitarnya sehingga akan meningkatkan kemampuan empati seseorang.

Secara kognitif, seorang perawat yang berperilaku empati mengetahui apa yang orang lain rasakan. Pada komponen ini didapatkan bahwa empati perawat dalam kategori baik dengan perawat yang menyatakan selalu berinteraksi langsung dengan pasien untuk bisa mengetahui keadaan pasien dan juga penting bagi perawat untuk mengetahui keluhan yang dirasakan pasien. Namun tingkat kognitif empati ini rendah tentang perawat yang membayangkan melakukan hal yang sama dengan yang dilakukan pasien untuk dapat merasakan apa yang dirasakan pasien tersebut. Perawat mengatakan bahwa hal ini disebabkan oleh beban kerja berlebihan yang dimiliki oleh perawat, sehingga mereka mengatakan tidak mempunyai waktu untuk hal tersebut.

Secara afektif, perawat yang berperilaku empati memahami apa yang orang lain rasakan dan mencoba melakukan sesuatu sebagai bentuk kepeduliannya. Pada komponen afektif ini, empati perawat dikategorikan baik sebab perawat menyatakan tidak pernah merasa lebih senang membantu pasien jika diberi imbalan dan menyatakan selalu merawat pasien dengan tulus serta dengan sabar mendengarkan keluhan-keluhan yang pasien rasakan. Tetapi perawat yang memanggil nama pasien dengan nama panggilan masih rendah. Hal ini dikarenakan perawat ketika berinteraksi dengan pasien masih lebih berfokus pada fisik saja dan sering melupakan sisi psikologis pasien, karena pasien akan 
merasa lebih senang dengan perawat dan lebih mudah menjalin hubungan dengan pasien saat kita sudah menjalin hubungan saling percaya, salah satunya dengan menggunakan panggilan kesukaan pasien.

Hasil penelitian ini jelas menunjukkan bahwa tingkat empati perawat di rumah sakit ini baik, namun tidak dapat dipungkiri bahwa masih banyak komplain oleh pasien maupun keluarga pasien yang sama sekali tidak puas dengan pelayanan yang diberikan oleh rumah sakit ini. Tidak jarang kita akan menemukan berita, baik dari koran maupun media, yang menunjukkan ketidakpuasan pasien terhadap pelayanan yang diterima. Kebebasan masyarakat saat ini untuk berpendapat, seharusnya dimanfaatkan dengan baik oleh rumah sakit untuk terus meningkatkan dan melakukan evaluasi tentang kepuasan pasien terhadap pelayanan kesehatan yang diterima pasien, agar tidak ada lagi komplain-komplain masyarakat yang muncul ke publik.

Seorang perawat ketika berinteraksi dengan pasien harus berfokus bukan hanya pada fisik saja tetapi juga psikologis pasien, hal ini untuk memahami setiap permasalahan yang mungkin ditunjukkan oleh pasien saat berinteraksi. Tetapi pada kenyataanya perawat sering sekali melupakan kebutuhan psikologis pasien ini. Reynold dan Scott pada [6] mengatakan bahwa tinggi rendahnya empati yang diperlihatkan oleh perawat dalam berhubungan dengan pasien adalah karena rendahnya pengetahuan dan keinginan untuk dapat mengetahui situasi pasien, serta ketidakseimbangan antara beban kerja dengan kemampuan, rendahnya motivasi dan kurangnya keinginan perawat untuk menjalin hubungan dengan pasien.

\section{Kesimpulan}

Kesimpulan penelitian ini secara keseluruhan menunjukkan bahwa gambaran empati perawat di RSUP H. Adam Malik Medan dalam kategori baik. Empati berdasarkan komponen kognitif dan afektif, secara terpisah juga menunjukkan bahwa empati perawat di rumah sakit ini sudah dalam kategori baik. Secara kognitif, empati perawat di rumah sakit ini nyatakan oleh keinginan perawat untuk berinteraksi langsung dengan pasien untuk bisa mengetahui apa yang pasien rasakan, sedangkan secara afektif, perawat menyatakan merawat pasien dengan tulus dan dengan sabar mendengarkan keluhan-keluhan yang pasien rasakan.

\section{Referensi}

[1] Fatimah., Elita, V., \& Wahyuni, S. (2010). Gambaran Tipe Empati Perawat Jiwa di Rumah Sakit Jiwa Tampan Pekanbaru. Jurnal Keperawatan, Vol.3(2)

[2] Goleman, D. (2007). Emotional Intelligence, Mengapa EQ Lebih Penting daripada IQ. Jakarta: Gramedia Pustaka Utama

[3] Koestner, R., Franz, C., \& Weinberger, J. (1990). The Family Origin of Empathic Concern: A 26-year Longitudinal Study. Journal of Personality and Social Psychology, 58, 709-717. Retrieved June 23, 2016, from ncbi.nlm.nih.gov/pubmed/

[4] Marcysiak, M., Dabrowska, O., \& Marcysiak M.B. (2014). Understanding The Concept of Empathy in Relation to Nursing. Prog Health Sci 2014, Vol 4, No 2. Retrieved September 18, 2015

[5] Penprase, B., Oakley, B., Ternes, R., \& Driscoll, D. (2012). Empathy as a Determining Factor for Nursing Career Selection. Journal of Nursing Education 2013, Vol. 52, No. 4. Retreived September 18, 2015

[6] Reynolds, W.J,. \& Scoot, B. (2000). Do Nurses and The Professional Helpers Normally Display Much Empathy?. Journal of Advanced Nursing. 31(1), 226-234, Retrieved June 23, 2016, from ncbi.nml.nih.gov/pubmed

[7] Rohmah, R. F. (2010). Tingkat Empati dan Sikap Altruistik pada perawat Rumah Sakit Umum dengan Rumah Sakit Jiwa, Skripsi Psikologi, Universitas Muhammadiyah Surakarta download.portalgaruda.org/article.php?article=4806\&val=434

[8] Taufik. (2012). Empati Pendekatan Psikologi Sosial. Jakarta: Rajawali. 